Br Heart f 1986;56:299-301

\title{
Editorial
}

\section{Is atrial natriuretic peptide really a hormone?}

\author{
R J LINDEN, M F KNAPP \\ From the Department of Cardiovascular Studies, University of Leeds
}

Since the 1950s when granules were first observed histologically within the atrial wall there has been intense interest in their function. Two early key papers were those of Marie et $a l^{1}$ and de Bold, ${ }^{2}$ who showed that the granulation was related to the water/electrolyte balance, although a first time reader's starting point should be the meticulous histological investigation of Jamieson and Palade. ${ }^{3}$

On pages 302-16 of this issue of the British Heart fournal Genest gives an excellent historical account of this exciting research, much of which has been conducted at the Clinical Research Institute of Montreal.

There has been remarkably rapid progress in biochemical knowledge about atrial natriuretic peptides and perhaps now is the time to pause and take stock of the evidence about their postulated physiological functions.

Because in humans and in rats the atrial natriuretic factor is elaborated and localised in the granules of the atrial cardiocytes and is released in the blood, it is suggested that the atrial natriuretic factor is "a true circulatory hormone". ${ }^{4}$ But is there any evidence for the usual process of secretion from the atrial muscle cell? Certainly there is no evidence that the plasma concentrations attained during applied physiological stimuli (such as stretch of left atrial wall) can evoke acute responses. There is only evidence that large doses or large infusions that produce pharmacological concentrations of atrial natriuretic peptide have effects on the blood vessels (arteries, arterioles, veins), causing relaxation, particularly of precontracted muscle, and on the kidneys, causing natriuresis and diuresis.

Little is yet known of the biosynthesis and processing of atrial natriuretic peptide in, and its release from, the cardiocytes. Interpretation of the observed changes in granulation in relation to changes in fluid balance $^{12}$ is at present difficult in view of studies ${ }^{56}$

Requests for reprints to Professor R J Linden, Department of Cardiovascular Studies, University of Leeds, Leeds LS2 9JT. which suggest that granulation is dependent on release rather than synthesis, with low granularity apparently indicating high biosynthesis and turnover; also, in cultured cardiocytes there was an inverse relation between granulation and release of atrial natriuretic peptide. ${ }^{7}$ It seems likely, however, that in some circumstances low granularity will be associated with low biosynthesis. Exocytosis has not been seen despite specific attempts to detect it in several electron microscope studies, ${ }^{37}$ so it is still not certain that the cardiocytes secrete atrial natriuretic peptides by mechanisms analogous to those found in established endocrine organs. Low molecular weight forms are, however, found in plasma and again controversy is rife, evidence being presented both for the release of the high molecular weight form, for the later cleavage in plasma, ${ }^{89}$ and for the release of the low molecular weight form. ${ }^{10}$

Few studies have considered quantitatively the problem of the possible physiological stimuli for release and in these no evidence has been provided of a causative relation between stimuli within the physiological range, a rise in the plasma concentration of atrial natriuretic peptide, and the response of natriuresis and diuresis. For instance, the secretion of atrial natriuretic peptide and a causative relation have been implied ${ }^{11}$ in the diuresis and natriuresis arising from stimulation of receptors in the atriathe so-called volume receptors. ${ }^{12}$ Stimulation of atrial receptors is known reflexly to cause a water diuresis and small natriuresis ${ }^{13}$ but afferent nerves in the vagi are necessary for these responses to occur. When a large balloon was distended in the left atrium of anaesthetised ${ }^{14}$ or unanaesthetised dogs ${ }^{15}$ to stretch it and raise left atrial pressure to the top end of the pressure range in this animal (12-15 $\mathrm{mm} \mathrm{Hg}$ ) the plasma concentration of atrial natriuretic peptide increased by about 24 and 80 $\mathrm{fmol} / \mathrm{ml}$ respectively $(60$ and $200 \mathrm{pg} / \mathrm{ml}$, assuming $M_{\mathrm{r}}=2.5 \mathrm{~K}$ daltons), with increases of the same magnitude whether or not the hearts were innervated. Knapp et al, however, obtained no natriuresis 
when this intervention was performed after atrial receptor denervation, ${ }^{16}$ indicating that the diuresis and natriuresis resulting from stimulation of atrial receptors ${ }^{17}$ were not caused by atrial natriuretic peptide. We suggested that such evidence must call seriously into question the claim that atrial natriuretic peptides are released into plasma in sufficient concentration for natriuresis to be a normal physiological function of these substances.

These investigations also support the contention that the plasma concentrations of atrial natriuretic peptide that evoke responses after infusion are much higher than those attained by stretching the atria or in disease. Normal endogenous basal concentrations of atrial natriuretic peptide are reported to be below $40 \mathrm{fmol} / \mathrm{ml}(100 \mathrm{pg} / \mathrm{ml})^{14151819}$ and raised concentrations after intervention or in pathological conditions are generally $<200 \mathrm{fmol} / \mathrm{ml} .^{141518-23}$ Even grossly unphysiological volume expansions of $30-40 \%$ of blood volume produced increases of only 4,11 , and $100 \mathrm{fmol} / \mathrm{ml}$ respectively. ${ }^{182425}$

From the evidence of Goet $z^{15}$ it is possible to put the data from infusions of atrial natriuretic peptide into the context of these very low endogenous levels. Goetz reported plasma atrial natriuretic peptide concentrations of 170 and $300 \mathrm{fmol} / \mathrm{ml}$ in conscious dogs after infusions of atriopeptin III of 10.3 and 20.6 $\mathrm{pmol} / \mathrm{kg} / \mathrm{min}$ respectively ${ }^{15}$; thus infusions as low as $10.3 \mathrm{pmol} / \mathrm{kg} / \mathrm{min}(25.8 \mathrm{ng} / \mathrm{kg} / \mathrm{min})$ would give plasma concentrations of far in excess of most of the reported endogenous concentrations. Yet Goetz reported no natriuresis or diuresis at these concentrations ${ }^{15}$; he found that a minimum infusion rate of $412 \mathrm{pmol} / \mathrm{kg} / \mathrm{min}(1030 \mathrm{ng} / \mathrm{kg} / \mathrm{min})$ was necessary to produce natriuresis. Similar analysis of infusions in man leads to comparable values with infusions of about $50 \mathrm{ng} / \mathrm{kg} / \mathrm{min}$ resulting in plasma concentrations of atrial natriuretic peptide 212627 in the pathological range. Very few published reports used infusion rates as low as those of Goetz ${ }^{15}$; most reports of the effects of atrial natriuretic peptide used doses within the pharmacological range and are thus unlikely to be useful in elucidating its physiological function.

The use of various high levels of infusion probably goes some way to explain the many contradictions that have emerged about the postulated functions and mechanisms of action of atrial natriuretic peptide, and these are exacerbated by the fact that most reviewers in discussing mechanisms of action still include early studies in which impure atrial extracts were used. These controversies include: disagreements about the site or sites of action in the kidney ${ }^{28-31}$; the apparent paradox of in vitro vasodilatation and in vivo falls in blood pressure with the findings in vivo of an increase in peripheral resistance, ${ }^{32}$ for which the current explanations are falling cardiac output and changes in capacitance ${ }^{32}$; the finding that vascular selectivity is only partly related to vascular receptor binding ${ }^{33}$; that the vascular effects are endothelium independent in contrast with other hormonal vasodilators ${ }^{33}$; and the dissociation of excretion of sodium from the levels of cyclic guanosine monophosphate in plasma and urine. ${ }^{28}$ The fact that high concentrations of atrial natriuretic peptide are found in patients with severe heart failure ${ }^{22}$ but are not associated with diuresis and natriuresis leads to claims that such patients may be resistant to the renal effects of endogenous atrial natriuretic peptide or that other factors (for example the renin-angiotensin-aldosterone system) may counteract the polyuric action of atrial natriuretic peptide in cardiac failure. But the high concentrations of the peptide could be incidental.

The excitement created by the discovery of atrial natriuretic peptides is understandable. The search for the postulated natural natriuretic substance has continued relentlessly for decades; and ever since the early experiments of Henry et al in 1956 in which they showed that distension of the left atrium by a balloon results in diuresis, ${ }^{34}$ the atria have been seen as being important in fluid regulation. The possibility of tying these two strands together has been too much for the theorists. ${ }^{1135}$ That alterations in fluid balance result in changes in atrial natriuretic peptide both in the atria and plasma is not in dispute and it does suggest a role that is linked with volume regulation. The suggestion that atrial stretch alone, that is without nerves being involved, is an adequate stimulus to raise the plasma concentration sufficiently to evoke responses, however, has not yet been demonstrated. It is difficult to understand how this postulated system of control of fluid balance may be working; stretching that causes leakage of atrial natriuretic peptide from atrial muscle seems an unlikely stimulus for a complex hormonal system that controls blood volume. At present it is impossible to determine whether the concomitant changes in atrial natriuretic peptide and fluid balance indicate a role in control of fluid homoeostasis or whether the observed changes are secondary to fluid imbalance. The reported changes in endogenous concentrations appear to be too small to be important in short term control but it is possible that in the long term small but prolonged changes in the concentration of atrial natriuretic peptide have a role in the control of body sodium - a hypothesis that it may be too difficult to test.

\section{References}

1 Marie JP, Guillemot H, Hatt PY. Le degre de granu- 
lation des cardiocytes auricularies. Etude planimetrique au cours de differents apports d'eau et de sodium chez le rat. Pathol Biol (Paris) 1976;24: 549-54.

2 de Bold AJ. Heart atria granularity effects of changes in water-electrolyte balance. Proc Soc Exp Biol Med 1979;161:508-11.

3 Jamieson JD, Palade GE. Specific granules in atrial muscle cells. f Cell Biol 1964;123:151-72.

4 Genest J, Cantin M. Regulation of body fluid volume: the atrial natriuretic factor. News in Physiological Sciences 1986;1:3-5

5 Ackermann U, Irizawa TG. Synthesis and renal activity of rat atrial granules depend on extracellular volume. Am f Physiol 1984;247:R750-2.

6 Takayanagi R, Tanaka I, Maki M, Inagami T. Effects of changes in water-sodium balance on levels of atrial natriuretic factor messenger RNA and peptide in rats. Life Sci 1985;36:1843-8.

7 Cantin M, Dagenais N, Salmi L, et al. Secretory patterns of atrial natriuretic factor (ANF) by cultured cardiocytes of right and left atrium from newborn and adult rats. Clin Exp Hypertens 1985;A7:685-705.

8 Glembotski CC, Wildey GM, Gibson TR. Molecular forms of immunocative atrial natriuretic peptide in the rat hypothalamus and atrium. Biochem Biophys Res Commun 1985;129:671-8.

9 Bloch KD, Scott JA, Zisfein JB, et al. Biosynthesis and secretion of proatrial natriuretic factor by cultured rat cardiocytes. Science 1985;230:1168-71.

10 Vuolteenaho O, Arjamaa O, Ling N. Atrial natriuretic polypeptides (ANP): rat atria store high molecular weight precursor but secrete processed peptides of 25-35 amino acids. Biochem Biophys Res Commun 1985;129:82-8.

11 Blaine EH. Emergence of a new cardiovascular control system: atrial natriuretic factor. Clin Exp Hypertens 1985;A7:839-50.

12 Gauer OH, Henry JP. Circulatory basis of fluid volume control. Physiol Rev 1963;43:423-81.

13 Ledsome JR, Linden RJ. The role of left atrial receptors in the diuretic response to left atrial distension. f Physiol (Lond) 1968;285:445-53.

14 Ledsome JR, Wilson N, Courneya CA, Rankin AJ. Release of atrial natriuretic peptide by atrial distension. Can f Physiol Pharmacol 1985;63:739-42.

15 Goetz KL. Lack of correlation between circulating atrial natriuretic factor and the natriuretic response elicited by atrial distension. In: Hainsworth R, Mary DASG, McWilliam PN, eds. Cardiogenic reflexes. Oxford: Oxford University Press, 1986 (in press).

16 Knapp MF, Hicks MN, Linden RJ, Mary DASG. Evidence against ANP as a natriuretic hormone during atrial distension. F Endocrinol 1986;109:R5-R8.

17 Linden RJ, Kappagoda CT. Atrial receptors. Cambridge: Cambridge University Press, 1982.

18 Lang RE, Thölken H, Ganten D, Luft FC, Ruskoaho $\mathrm{H}$, Unger Th. Atrial natriuretic factor-a circulating hormone stimulated by volume loading. Nature 1985;314:264-6.

19 Sagnella GA, Markandu ND, Shore AC, MacGregor GA. Raised circulatory levels of atrial natriuretic peptides in essential hypertension. Lancet 1986;i:179-81.

20 Burnett JC, Kao PC, Hu DC, et al. Atrial natriuretic peptide elevation in congestive heart failure in the human. Science 1986;231:1145-7.

21 Tikkanen I, Fyhrquist F, Metsärinne K, Leidenius R. Plasma atrial natriuretic peptide in cardiac disease and during infusion in healthy volunteers. Lancet 1985;ii:66-9.

22 Tikkanen I, Metsärinne K, Fyhrquist F. Atrial natriuretic peptide in paroxysmal supraventricular tachycardia. Lancet 1985;ii:40-1.

23 Tunny TJ, Gordon RD. Plasma atrial natriuretic peptide in primary aldosteronism (before and after treatment) and in Bartter's and Gordon's syndromes. Lancet 1986;i:272-3.

24 Sagnella GA, Markandu ND, Shore AC, MacGregor GA. Effects of changes in dietary sodium intake and saline infusion on immunoreactive atrial natriuretic peptide in human plasma. Lancet 1985;ii:1208-11.

25 Richards AM, Cleland J, Tonolo G, et al. Plasma alpha human atrial natriuretic peptide (ANP) response to an acute intravenous saline load [Abstract]. Clin Sci 1986;70(suppl 13):13P.

26 Genest J. The atrial natriuretic factor. Br Heart $\mathcal{f}$ 1986;56:302-16.

27 Espiner EA, Crozier IG, Nicholls MG, Cuneo R, Yandle TG, Ikram $H$. Cardiac secretion of atrial natriuretic peptide. Lancet 1985;ii:398-9.

28 Seymour AA. Renal and systemic effects of atrial natriuretic factor. Clin Exp Hypertens 1985;A7: 887-904.

29 Baum M, Toto RD. Lack of a direct effect of atrial natriuretic factor in the rabbit proximal tubule. $A m \mathcal{F}$ Physiol 1986;250:F66-9.

30 Burnett JC, Granger JP, Opgenorth TJ. Effects of synthetic atrial natriuretic factor on renal function and renin release. Am f Physiol 1984;247:F863-6.

31 Brown J. Effect of atrial natriuretic peptide on the excretion of lithium in man [Abstract]. $\mathcal{F}$ Physiol (Lond) 1986;374:47P.

32 Breuhaus BA, Saneii HH, Brandt MA, Chimoskey JE. Atriopeptin II lowers cardiac output in conscious sheep. Am F Physiol 1985;249:R776-80.

33 Winquist RJ, Napier MA, Vandlen RL, et al. Pharmacology and receptor binding of atrial natriuretic factor in vascular smooth muscle. Clin Exp Hypertens 1985;A7:869-84.

34 Henry JP, Gauer OH, Reeves JL. Evidence of the atrial location of receptors influencing urine flow. Circ Res 1956;4:85-90.

35 Sagnella GA, MacGregor GA. Cardiac peptides and the control of sodium excretion. Nature 1984;309: 666-7. 